\title{
DIGITIZING ABAHATA AL-JABARI METHOD USING LACIP SKILL THEORY TO SUPPORT LEARNING AL-QURAN FOR CHILDREN WITH LOW-FUNCTIONING AUTISM: A REVIEW TOWARDS AL-QURAN PERSPECTIVE ${ }^{\circ}$
}

\author{
Nurul Nadhrah Kamaruzaman ${ }^{1}$ \\ Nazean Jomhari, ${ }^{2}$ Zulkifli Mohd Yusoff ${ }^{3}$
}

ABSTRACT

Children with Low-Functioning Autism (LFA) experience great difficulty in learning due to lack of concentration and other impairments. However, this study has taken a wise step by focusing on the strengths of the children with LFA and maximizes it rather than solely on the deficiencies incurred by them. The objective of this study is to digitize the ABAHATA Al-Jabari method by developing an interactive game to support learning Al-Quran for children with LFA. This study introduces the integration of Listening, Arranging, Constructing, Imitation and Pronunciation (LACIP) skills as the needs for children with LFA in their learning process. Furthermore, this study presents the discussions on the LACIP skill theory from the Al-Quran perspective thus applies it in the design and development of the game prototypes. Therefore, by converting the ABAHATA AL-Jabari method into the digital form, this study is hoped to offer an alternative way for children with LFA to learn Al-Quran. Hence provide them with opportunities to study Al-Quran like other normal Muslim children.

Keywords: Digitize, Abahata Al-Jabari, Children with LFA, Al-Quran, LACIP.

() This article was submitted on: 10/04/2015 and accepted for publication on: 15/05/2015.

1 Faculty of Computer Science and Information Technology, nadhrah0111@siswa.umedu.my

2 Faculty of Computer Science and Information Technology, email: nazean@um.edu.my

3 Centre of Quranic Research (CQR), University of Malaya, email: zulkifliy@um.edu.my 


\subsection{INTRODUCTION}

The importance of Al-Quran in Muslims' daily life is something that cannot be denied. However, there are many children in Malaysia who are still struggling and having a problem in learning Al-Quran especially children with autism. Various studies and researches have been done regarding this matter (Chik 1986; Madihah Haji Mohamad 1992; Noh 2004). One of the major factors that have been discovered is the implementation of inappropriate and unsuitable techniques in learning and teaching Al-Quran among students. Teachers, parents and students are supposedly smart enough in choosing which method and technique that is most suitable with the level of students.

There are many methods and techniques in learning and teaching AlQuran. With the development of science and technology, all the learning methods and techniques experience a rapid evolution and improvement in order to ensure the students can master the skills in learning Al-Quran. It includes reading, memorizing and understanding the "Tajweed" rules. There are several methods and technique that have been implemented in Malaysia such as Baghdadiyah, Qiraati, Iqra', Hattawiyah and ABAHATA Al-Jabari. Basically, all the methods and techniques are focusing on recognizing and identifying letters in Al-Quran. Among all the methods and techniques stated, there is no such thing as the best method and techniques in learning and teaching Al-Quran. It also depends on the level of students and the way the methods and techniques delivered. Nevertheless, for children with autism, the ABAHATA Al-Jabari learning method is believed able to be implemented for them as the method applies learning through singing that could attract their psychological and behavioural in learning Al-Quran.

\subsection{BACKGROUND STUDY}

\subsection{Learning Al-Quran with ABAHATA Al-Jabari Learning Method}

Drs.H. Yusuf Sodik was the founder of ABAHATA Al-Jabari method since year 1991. This method originated from Indonesia and came to Malaysia in the year 2012. The ABAHATA Al-Jabari method is certainly a simple and enjoyable technique especially to master the reading of Al-Quran. It is also a suitable and appropriate method for the people from all age including children and adults (Irna Wati Amusin 2012). The main element in learning using ABAHATA AlJabari method is the focus on Memory Mind Mapping, which the hijaiyah letters are arranged based on Arabic words and carry certain meaning (See Figure 1). From that, the hijaiyah letters need to be remembered through singing with Badr Nasheed (selawat badar) rhythm. This singing technique is 
one of the interesting approaches for teaching pedagogy because through singing, it will be easy for children to memorize and recognize something.

Another advantage of the ABAHATA Al-Jabari method is that it contains various elements that complement each other as it combines mastery in reading and writing skills. According to (Irna Wati Amusin 2012), based on her previous studies, there is no thesis or dissertation present about the combination of two skills in one method of learning Al-Quran such as reading and writing. Usually, the methods produced are focus and emphasize solely on one skill. Apart from that, the learning and teaching method of the ABAHATA Al-Jabari, were arranged systematically started from easy level, medium and hard. In other word, this method is going through the process of introduction, comprehension and mastery. As for the lesson contents, ABAHATA Al-Jabari method provides materials which include reading and writing as well as "Tajweed" knowledge. Therefore, this method gives an opportunity for students to be independent and at the same time be cooperative with others as the key learning of this method is through observing and reading as well as imitating and writing.

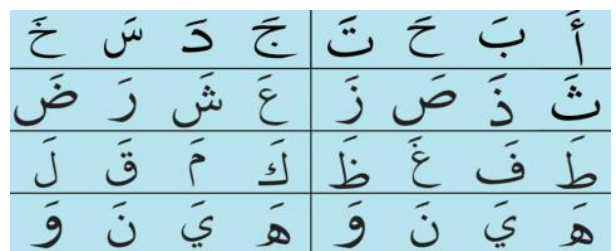

Figure 1: ABAHATA Al-Jabari Method-Memory Mind Mapping

\subsection{Low-Functioning Autism (LFA)}

Generally when it comes to autism, the public always categorize it into two categories which are High-Functioning Autism (HFA) and Low-Functioning Autism (LFA). Research shows that LFA indicates that the decoding skill has not fully developed while HFA indicates a performance level that is almost similar to normal (Rojahn, Lederer et al. 1995). An individual suffering from LFA experience the severe behavioral problem and limitation in communication that causes them to be regarded as unstable (Eagle 2002). Some of them are inclined to do things that may be harmful to themselves such as banging their head, hitting and biting themselves (Volkmar 2007). Therefore, it is not surprising if an individual with LFA is not able to think and behave like their other typical peers. For children with LFA, they often have a number of problems such as educational opportunities, physical limitation and behavior limitation. 
In the educational aspect, an LFA individual is not able to give a good and appropriate response towards the conventional approach of delivering an education strategy. All impairments in them make it challenging in teaching and learning for children with LFA. This situation happens because of their low cognitive skills as compared to other children. Besides that, they also have difficulties in understanding and representing tasks which involve symbolic or abstract thinking (Scarlett 2006). However, children with LFA do well on tasks involving visual skills and because of that, the educational goals set for them should be structured and involve with something related to visual stimulation.

\subsection{LACIP Skill}

The study on the skills of children with autism in their learning process has received an encouraging response from other researchers. Through the research done, they discovered many interesting findings regarding the skill level of children with autism. From the in-depth literary studies, we have identified five skills that need to be emphasized for children with autism which are Listening, Arranging, Constructing, Imitation and Pronunciation (LACIP). Table 1 presents the summarization of the findings gathered from the literature review studies.

\begin{tabular}{|c|c|c|}
\hline Author \& Year & Remark & Skill \\
\hline $\begin{array}{ll}\text { Grandin } & 1995 ; \\
\text { Grandin } & 1995 ; \\
\text { Grandin } & 1997 ; \\
\text { Attwood } & 1998 ; \\
\text { Jolliffe, } & \\
\text { Lansdown } & \text { et al. } \\
2001 ; & \text { Birch } \\
2003) & \end{array}$ & $\begin{array}{l}\text { Individual with autism is very sensitive to loud noise, } \\
\text { unexpected sound }\end{array}$ & \\
\hline $\begin{array}{l}\text { (O'Connor } \\
2011)\end{array}$ & $\begin{array}{l}\text { Person with autism always encounters problem in } \\
\text { processing complex auditory information especially } \\
\text { those relating to speech }\end{array}$ & 营 \\
\hline (Fithri 2011) & $\begin{array}{l}\text { The first step taken in the therapy for children with } \\
\text { autism is to make them listen to the recitation of Al- } \\
\text { Quran. }\end{array}$ & \\
\hline $\begin{array}{l}\text { (Zulkurnaini, } \\
\text { Kadir et al. } \\
2012 \text { ) }\end{array}$ & $\begin{array}{l}\text { Listening to Al-Quran recital can increase the alpha } \\
\text { band more than listening to classical music }\end{array}$ & \\
\hline (Gus 2000) & Autisms like to arrange objects according to series, & $\sigma \approx$ \\
\hline
\end{tabular}




\begin{tabular}{|c|c|c|}
\hline Author \& Year & Remark & Skill \\
\hline & $\begin{array}{l}\text { colours or peculiar pattern and classify it based on } \\
\text { similarities or differences between those objects }\end{array}$ & \\
\hline $\begin{array}{l}\text { (Gus 2000; Van } \\
\text { Rijn } \quad \text { and } \\
\text { Stappers 2008) }\end{array}$ & $\begin{array}{l}\text { Autisms can notice very quickly any small changes to } \\
\text { the arrangement they had made which can cause them } \\
\text { to be angry or sad }\end{array}$ & \\
\hline $\begin{array}{l}\text { (Dewey, Lord et } \\
\text { al. 1988) }\end{array}$ & $\begin{array}{l}\text { Constructive toy is the most efficient way of forming } \\
\text { complex social interaction among autistic children }\end{array}$ & \multirow{3}{*}{ 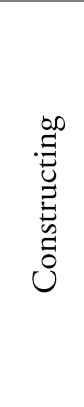 } \\
\hline (Frost 1992) & $\begin{array}{l}\text { The desire of children to invent something will be } \\
\text { achieved through open-ended materials such as blocks, } \\
\text { paints, scissors, paste, paper, carpentry tools, wood, } \\
\text { sand and water }\end{array}$ & \\
\hline $\begin{array}{l}\text { (Darlington } \\
\text { 2001) }\end{array}$ & $\begin{array}{l}\text { Constructive toy such as Lego can attract the interest of } \\
\text { children because they seem to get satisfaction when two } \\
\text { Lego bricks lock to each other }\end{array}$ & \\
\hline $\begin{array}{l}\text { (Smith and } \\
\text { Bryson 1994) }\end{array}$ & $\begin{array}{l}\text { Imitation is a non-verbal social communication skill } \\
\text { that is lacking among children with autism }\end{array}$ & \multirow{5}{*}{ 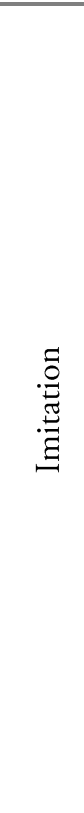 } \\
\hline $\begin{array}{l}\text { (Osterling and } \\
\text { Dawson 1994; } \\
\text { Robins, Fein et } \\
\text { al. 2001) }\end{array}$ & $\begin{array}{l}\text { Autism finds it difficult to imitate people around them } \\
\text { as well as responding to call from others }\end{array}$ & \\
\hline $\begin{array}{l}\text { (Rogers 1999; } \\
\text { Rogers and } \\
\text { Bennetto 2000; } \\
\text { Carpenter, } \\
\text { Pennington et al. } \\
2002)\end{array}$ & $\begin{array}{l}\text { The development of a broader social communication } \\
\text { for children with autism can be achieved by targeting } \\
\text { their imitation skill }\end{array}$ & \\
\hline (Meltzoff 2002) & $\begin{array}{l}\text { A newborn baby possesses the ability to imitate the } \\
\text { simple movements of their parents }\end{array}$ & \\
\hline (Ingersoll 2008) & $\begin{array}{l}\text { The ability of children with autism to imitate is lower } \\
\text { compared to typical children especially in spontaneous } \\
\text { imitation }\end{array}$ & \\
\hline $\begin{array}{l}\text { (Stone and } \\
\text { Yoder 2001) }\end{array}$ & $\begin{array}{l}\text { Imitation approach is closely related with the language } \\
\text { learning }\end{array}$ & \multirow{2}{*}{  } \\
\hline $\begin{array}{l}\text { (Ross and Greer } \\
2003 \text { ) }\end{array}$ & $\begin{array}{l}\text { Children with autism were encouraged to imitate } \\
\text { motor behavior as it would make them more open in } \\
\text { expressing their desire through their spoken words }\end{array}$ & \\
\hline
\end{tabular}

Table 1: Review on LACIP Skill 


\subsection{METHODOLOGY}

\subsection{New Implementation}

Individual with LFA is a strong visual and auditory learner. These children with LFA require various types of toys and learning aids that help to stimulate their skills that are employed during learning. The usage of these learning materials is inconvenient and difficult to carry and move from one place to another place. In this digital era, these children nowadays are comfortable in using devices such as iPad, tablets, laptops and any other high-tech gadget (Prensky 2001). It might be boring and uninteresting to present the traditional teaching and learning material to them. The educational system needs to utilize and be more aggressive in competing with technologies and benefit from it (Nusir, Alsmadi et al. 2011). Therefore, this study aims to propose a new implementation by digitizing the ABAHATA Al-Jabari method in a game form to support learning Al-Quran for children with LFA. Besides that, this study highlights the adaptation of LACIP skill theory in the design and development of the game prototype. The main reason of this idea is because of its interactivity and convenience as it incorporates multimodal features such as music, sounds, videos, motions and animations. Although the traditional approach includes pictures and graphics, the digital form allows the children to access the material course easily as it is readily accessible only through one device.

\subsection{Preliminary Study}

Observation of five students with LFA with age ranging from five to twelve years old was conducted in order to get a better understanding about the children with LFA. The observation was done over a period of sixteen weeks (four months), and it was conducted in an Al-Quran learning class every Sunday from $10.00 \mathrm{am}$ until $2.00 \mathrm{pm}$.

Based on the observation, it was found that listening skill requires a combination of other skills in order to help them become more focused. This situation arises when they were listening to the recitation of the Al-Quran while arranging objects and constructing puzzles. This scenario supports the words from one of the teachers who said that the students need something that they like as the bait for them to become more focus in learning. Apart from that, listening skill is also closely linked with imitation and pronunciation skills whereby the students will eventually imitate and pronounce the sounds or words that they have been listening for several times and more.

From the observation in the Al-Quran class, it was found that they are very meticulous in categorizing certain things and this obviously can be seen 
while they were applying their arranging skills. They tend to arrange the certain material, according to type, color, shape and size. One of the arranging patterns that could be identified during the observation that was conducted was arranging and destroys. Usually, this involves the category of children at the early stage of autism. Many of the arrangement made are not complex and it gives them satisfaction when they destroy what they have arranged. Some of them liked to arrange the bottles that were labeled with hijaiyah letters lengthwise and then after a few minutes he will topple all the bottles. Meanwhile, some of them liked to arrange the sponges labeled with hijaiyah letters and disperse them after he feels satisfied and bored with the arrangement. However, while they were arranging things, the trainers will say out the hijaiyah letters on the flash card, sponge or bottles, and the students then followed the trainer in saying out the hijaiyah letters.

Throughout the observation session, an interesting chronology have been discovered which includes both arranging and constructing skills. In the early stage, normally the children will make a simple arrangement that is not too complex. The shape of their arrangement is usually done lengthwise, vertical or in a circle. The materials used are softer such as flash card, pictorial sponge, bottles and hijaiyah foam. Nevertheless, over time, the act of arranging things for these children will mean an act to form something that is more complex. The materials also used will be more concrete. For example, there was a student with LFA, who initially liked to arrange the flash card and pictorial sponge but later moved on to arrange a more concrete toys and more complex arrangement such as Lego. He managed to construct a pistol from the Lego arrangement.

Certainly, the pronouncing skill is closely related to imitation skill. Usually, in the Al-Quran class, the children with LFA will be guided by trainers to pronounce the hijaiyah letters by letting them imitate the movement of the mouth. After being repeated several times, the children seemed able to imitate and pronounce the sound of hijaiyah letters as produced earlier. Table 2 presents the summarization of the reviews from the observation conducted. Below are the pictures taken during the observation session in the Al-Quran class:-

\begin{tabular}{|l|l|l|l|l|}
\hline \multicolumn{1}{|c|}{ Skill } & Environment & \multicolumn{1}{c|}{ Actions } & Situation Assessment & \multicolumn{1}{c|}{$\begin{array}{c}\text { Further } \\
\text { Actions }\end{array}$} \\
\hline $\begin{array}{l}\text { (L) } \\
\text { Listenin } \\
\mathbf{g}\end{array}$ & $\begin{array}{l}\text { Students sit in } \\
\text { a conducive } \\
\text { environment } \\
\text { without any } \\
\text { noise }\end{array}$ & $\begin{array}{l}\text { Read manually } \\
\text { Read using digital } \\
\text { tools }\end{array}$ & $\begin{array}{l}\text { Trainer reads or plays } \\
\text { the Islamic rhyme/ } \\
\text { short chapter } \\
\text { repeatedly while } \\
\text { students do other }\end{array}$ & $\begin{array}{l}\text { Access and } \\
\text { record the time } \\
\text { is taken for } \\
\text { student to focus } \\
\text { on listening and }\end{array}$ \\
\hline
\end{tabular}




\begin{tabular}{|c|c|c|c|c|}
\hline & $\begin{array}{l}\text { interference } \\
\text { such as cars } \\
\text { and external } \\
\text { noises rooms }\end{array}$ & & $\begin{array}{l}\text { activity in relaxed } \\
\text { condition (See Figure } \\
\text { 2) }\end{array}$ & $\begin{array}{l}\text { reading } \\
\text { frequency }\end{array}$ \\
\hline $\begin{array}{l}\text { (A) } \\
\text { Arrangin } \\
\mathrm{g}\end{array}$ & $\begin{array}{l}\text { On the floor, } \\
\text { table }\end{array}$ & $\begin{array}{l}\text { Arrange the } \\
\text { Arabic alphabets } \\
\text { by using bottles, } \\
\text { flash cards and } \\
\text { foams }\end{array}$ & $\begin{array}{l}\text { Students arrange } \\
\text { without sequence (See } \\
\text { Figure 3) } \\
\text { Students helped by } \\
\text { trainer }\end{array}$ & $\begin{array}{l}\text { Access and } \\
\text { record to what } \\
\text { extent that the } \\
\text { students could } \\
\text { identify the } \\
\text { correct order }\end{array}$ \\
\hline $\begin{array}{l}\text { (C) } \\
\text { Constru } \\
\text { cting }\end{array}$ & $\begin{array}{l}\text { On the floor, } \\
\text { table }\end{array}$ & $\begin{array}{l}\text { Construct } \\
\text { materials that can } \\
\text { be combined and } \\
\text { form a new thing } \\
\text { i.e. lego, puzzle, } \\
\text { plasticine }\end{array}$ & $\begin{array}{l}\text { Trainer observes the } \\
\text { creativity performed } \\
\text { by students (See } \\
\text { Figure 4) }\end{array}$ & $\begin{array}{l}\text { Record the } \\
\text { students' work } \\
\text { to see the } \\
\text { progress } \\
\text { regarding the } \\
\text { complexity of } \\
\text { the construction } \\
\text { created }\end{array}$ \\
\hline $\begin{array}{l}\text { (I) } \\
\text { Imitatio } \\
\mathbf{n}\end{array}$ & $\begin{array}{l}\text { Physical } \\
\text { activity during } \\
\text { ablution and } \\
\text { prayer }\end{array}$ & $\begin{array}{l}\text { Bring students to } \\
\text { ablution and } \\
\text { prayer room }\end{array}$ & $\begin{array}{l}\text { Trainer helps the } \\
\text { students to imitate the } \\
\text { movement of prayer } \\
\text { and ablution } \\
\text { performed by another } \\
\text { trainer }\end{array}$ & $\begin{array}{l}\text { Access and } \\
\text { record to what } \\
\text { extent that the } \\
\text { students could } \\
\text { imitate even a } \\
\text { little } \\
\text { improvement }\end{array}$ \\
\hline $\begin{array}{l}(\mathrm{P}) \\
\text { Pronunc } \\
\text { iation }\end{array}$ & $\begin{array}{l}\text { While singing } \\
\text { or playing }\end{array}$ & $\begin{array}{l}\text { Pronounce and } \\
\text { sing together with } \\
\text { the trainer }\end{array}$ & $\begin{array}{l}\text { Sing continuously and } \\
\text { reward them if they } \\
\text { could pronounce } \\
\text { correctly }\end{array}$ & $\begin{array}{l}\text { Record the } \\
\text { Arabic alphabets } \\
\text { that are } \\
\text { pronounced by } \\
\text { students in } \\
\text { notebook }\end{array}$ \\
\hline
\end{tabular}

Table 2: Observation on LACIP Skills

\subsection{Design and Development of Al-Jabari Game Prototype}

The design and development of the Al-Jabari game prototype emphasize on two important aspects which are ABAHATA Al-Jabari method and LACIP skills theory. Also, this section discusses the relation between LACIP skill from the Al-Quran perspective thus applies it for the design of the game prototype.

The main menu page allows users to have the freedom in choosing any four categories provided according to their preferences. 


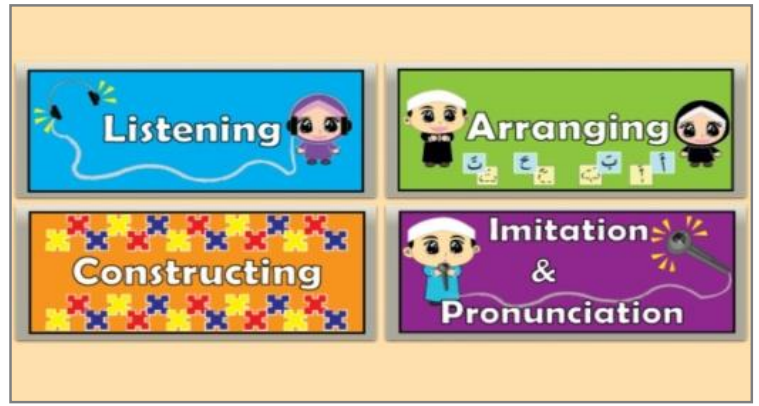

Figure 6(a): Main Menu Page

\section{Listening}

From the religious point of view, listening to Al-Quran is one of the worships that carries equal merit with reading the al-Quran itself. Allah (swt) says in the Al-Quran:

2. (this is the) Book (the Qur'ân) sent down unto You (O Muhammad), so let not Your breast be narrow there from, that You warn thereby, and a Reminder unto the believers. (Al-Araaf 7:2)

204. When the Qur'an is read, listen to it with attention, and hold your peace: that ye may receive mercy. (Al-Araaf 7: 204)

From the above verses, it is clear that Al-Quran is a blessing from Allah for those who listen to it attentively with the presence of mind. Furthermore, listening to the recitation of Al-Quran serves as a reminder, ultimate guidance as well as bringing peace and tranquility to one's heart. The sense of hearing is a blessing from Allah that one should be thankful. Listening skills is the first channel of accepting knowledge as early as the birth of a human being. According to (Yusoff 2005), the human being can capture sounds even when it is still in the form of a fetus. As Allah (swt) says in the Al-Quran:

78. And Allâh has brought You out from the wombs of Your mothers while You know nothing. And He gave You hearing, sight, and hearts that You might give thanks (to Allâh).

(An-Nahl 16: 78)

Based on the verses mentioned above, it is evident that listening skill is frequently emphasized and linked to the process of receiving knowledge. Therefore, this skill has also been applied in the development of the Al-Jabari game. Below are the prototypes of the Listening category with description: 


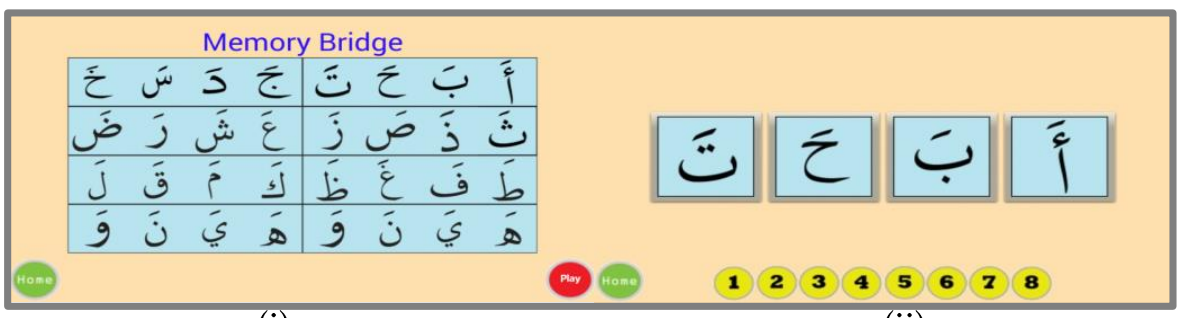

(i)

(ii)

Figure 6(b): Listening Page

This page displays the Memory Mind Mapping that consists of eight sections of hijaiyah letters. The audio of Al-Jabari Hijaiyah rhythm will be activated by clicking/ touching upon request. The user will be directed to the page shown in Figure 6(b-ii) by clicking/touching one part of hijaiyah letter from the Memory Mind Mapping. The sound of each hijaiyah letter will be produced once the button is clicked/ touched. The user can simply navigate to other sections of hijaiyah letter by clicking/ touching numbers of the section shown at the bottom of the page.

\section{Arranging and Constructing}

Allah (swt) says in the Al-Quran:

1. Blessed be He who sent down the criterion (of Right and wrong, i.e. This Qur'ân) to his slave (Muhammad) that He may be a warner to the 'Alamîn (mankind and jinns). (Al-Furqaan 25: 1)

From the verse, it is clear that Al-Quran was reveal from Allah to all mankind regardless of their conditions. Therefore, the learning of Al-Quran is not restricted only to normal person but people with disabilities such as children with LFA also deserved the same opportunity to learn Al-Quran. Parents and teachers should identify the children's strengths and make full use of it in order to help the Al-Quran learning process to become more effective. From the literature review and observation done, children with LFA like to arrange and construct and because of that, both skills need to be emphasized in their Al-Quran learning process.

From the Islamic perspective, there are few things that are relating to the arrangement element in learning Al-Quran. For example, Muslim scholars stated several manners that underlined the importance of proper arrangement in reading Al-Quran. 
32. And those who disbelieve say: "Why is not the Qur'ân revealed to Him All at once?" Thus (it is sent down In parts), that we may strengthen Your heart thereby. And we have revealed it to You gradually, In stages. (it was revealed to the Prophet In 23 years.). (Al-Furqaan 25: 32)

4. Or a little more; and recite the Qur'ân (aloud) in a slow, (pleasant tone and) style. (Al-Muzammil 73: 4)

From the above verses, Al-Quran should be read with "tarteel". "Tarteel" is a term from the Arabic word that is usually translated as recitation in proper order and with no haste. According to one of the Muslim Scholars, Ibn Kathir, " recite the Quran slowly, making the letters clear, for this is assistance in understanding and pondering the meaning of the Quran."

Considering all the Al-Quran verses and findings that are mentioned above, the development of the Al-Jabari game's prototype has highlighted another two skills which are arranging and constructing. Below are the prototypes of Arranging and Constructing category with description:-

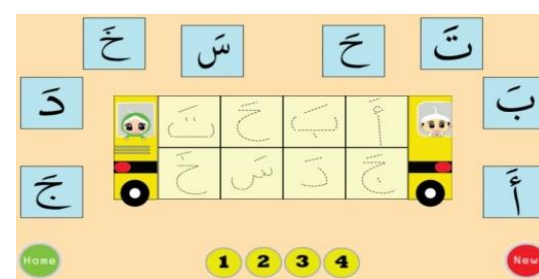

(i)



(ii)

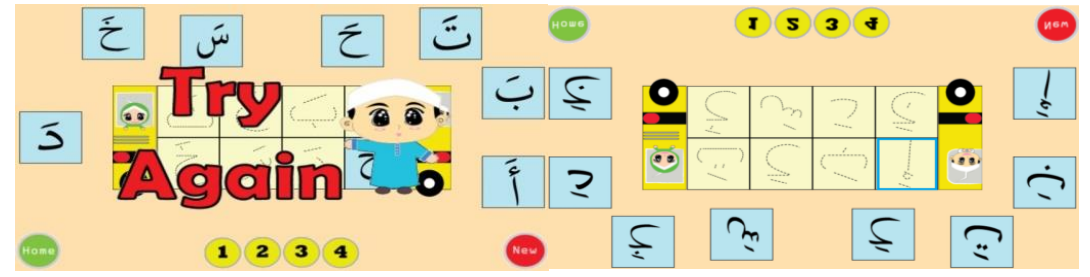

(iii)

(iv)

Figure 6(c): Arranging Page

This page requires the user to arrange the hijaiyah letters by dragging and matching the hijaiyah letters at the correct spaces provided. The user can simply navigate to other sections of hijaiyah letter by clicking/ touching numbers of the section shown at the bottom of the page. Reward and word of encouragement are also provided in order to motivate the user. Besides that, 
this page also provides a corrective suggestion as a clue for the user when he/she does not have an idea on how to get the correct answer.

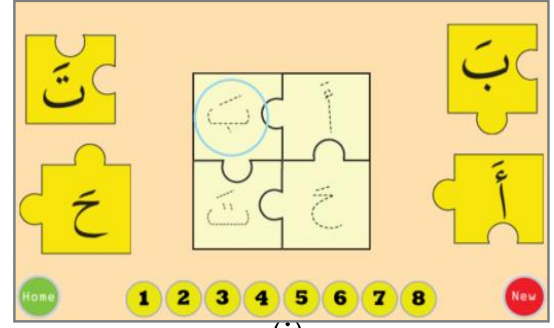

(i)

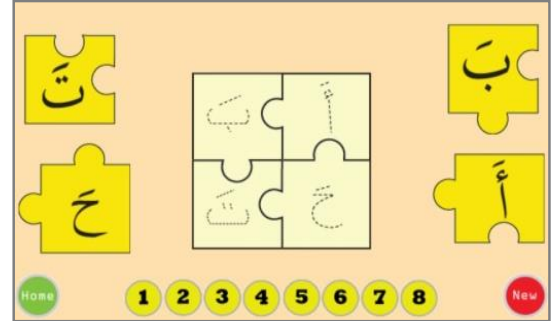

(ii)

Figure 6(d): Constructing Page

This page requires the user to construct the hijaiyah puzzles by dragging and matching the puzzles at the correct spaces provided. The user can simply navigate to other sections of hijaiyah letter by clicking/ touching numbers of the section shown at the bottom of the page. Similar to Arranging Page, Constructing Page also provides a reward, word of encouragement and corrective suggestion to the user.

\section{Imitation \& Pronunciation}

The Prophet Muhammad (PBUH) received his first revelations from the angel Jibril in a cave called Hira'. During the incident, the angel Jibril asked the Prophet Muhammad to "Read (Iqra)". The Prophet was afraid and replied, "I could not read." The angel Jibril hugged him until he could not breathe and asked the Prophet again to "Read". Once Again, the Prophet replied, "I could not read." This situation happened for three times and finally the angel Jibril released the Prophet and said:-

1. Read! In the Name of Your Lord, who has created (all that exists), 2. has created man from a clot (a piece of thick coagulated blood). 3. Read! and Your Lord is the Most Generous, 4. who has taught (the writing) by the pen [the first person to write was Prophet Idrees (Enoch)], 5. has taught man that which He knew not. (Al-Alaq 96: 1-5)

The Prophet Muhammad is illiterate who cannot read and write. The manner in which the angel Jibril sent the revelation to the Prophet Muhammad is by reading out the words from Allah to Prophet Muhammad (PBUH) who later repeated the words in front of the angel Jibril. The oldest Al-Quran learning technique called "Talaqqi and Musyafahah" is derived from this incident. The term "Talaqqi" means the meeting of the students and teacher in 
person. Meanwhile the term "Musyafahah" refers to the act of teaching where the teacher pronounces the word and sentence in the Al-Quran with emphasis on the movement of the lips and strictly observed by the student. By adopting the concept of this "Talaqqi and Musyafahah," the Al-Jabari game includes the imitation and pronunciation skills in the design and development of the game's prototype. Below is the prototype of Imitation \& Pronunciation category with description:-



Figure 6(e): Imitation \& Pronunciation Page

This page requires the user to click/ touch the hijaiyah button. Once it has been clicked/ touched, the mouth will pronounce the sound of hijaiyah letter. Through that, the user can imitate the movement of the mouth thus helping the user to pronounce the hijaiyah letter. The purpose of displaying only the mouth part is to allow the user to focus on the movement of the mouth in pronouncing the hijaiyah letter. Besides that, this strategy can avoid the view of the user from distracted with any other parts such as the eyes or nose. This matter is taken into account as the target users are children with autism who have difficulty in paying attention and focusing on something. The user can simply navigate to other sections of hijaiyah letter by clicking/ touching numbers of section shown at the bottom of the page.

\subsection{DISCUSSION}

The implementation of the appropriate and suitable learning method and technique would be ideal for increasing interest among children with LFA towards learning Al-Quran. In this study, the ABAHATA Al-Jabari method was chosen because it is considered suitable for children especially children with LFA. Moreover, the method emphasizes the singing approach which can attract and influence their psychological mood in learning. This study is motivated to make the learning material portable and easy access by children with LFA only through one device. Therefore, this study aims to digitize the ABAHATA AlJabari learning method by developing an interactive serious game to support learning Al-Quran for children with LFA. 
This study concentrates on the abilities and strengths of the children with LFA rather than solely on the deficiencies and challenges incurred by them. At the beginning, this study identified that the children with LFA are inclined to use several skills during their learning process which are Listening, Arranging, Constructing, Imitation and Pronunciation (LACIP). Because of that, this study has put a major step forward by incorporating LACIP skills with the creation of Al-Jabari game. Besides that, this study has discussed the relevance of LACIP skills from the Al-Quran perspective including the incident between the Prophet Muhammad and the angel of Jibril during his first revelation in a cave called Hira'.

\subsection{CONCLUSION}

As the conclusion, interest and strength of children with autism should be considered in developing learning game application because their brain development will be at the maximum level when they are interested and delighted in doing something. Therefore, every party including parents, experts, teachers and game developers should work together and be creative in diversifying the educating styles and techniques, thus improve the children's learning outcome. Lastly, this study is trying to offer an alternative way to support learning Al-Quran for the children with LFA by converting the traditional way of Abahata Al-Jabari method into the digital forms. With that, it is hoped that this study could contribute to the teaching of children with LFA in learning Al-Quran, thus offering them with more opportunities to study Al-Quran like other normal Muslim children.

\section{ACKNOWLEDGEMENT}

We would like to thank all the participants and their families from Yayasan Faqeh in collaboration with Centre Quranic Research, University of Malaya. This work was partially supported by Fundamental Research Grant Scheme [January-December 2013]. 


\subsection{REFERENCES}

Attwood, T. (1998). Asperger's syndrome: A guide for parents and professionals. Jessica Kingsley Pub.

Birch, J. (2003). Congratulations! It's Asperger Syndrome. Jessica Kingsley Publishers.

Carpenter, M., B. F. Pennington, et al. (2002). "Interrelations among social-cognitive skills in young children with autism." Journal of autism and developmental disorders 32(2): 91-106.

Chik, A. (1986). "Kaedah Amali Hayati: Satu Pendekatan Mengajar Pendidikan Islam. Kuala Lumpur." Dewan Bahasa dan Pustaka. Malaysia.

Darlington, J. (2001). "Humor, imagination and empathy in autism." Our Journey Through High Functioning Autism and Asperger Syndrome: A Roadmap: 31.

Dewey, D., C. Lord, et al. (1988). "Qualitative assessment of the effect of play materials in dyadic peer interactions of children with autism." Canadian Journal of Psychology/Revue canadienne de psychologie 42(2): 242.

E. M. D. a. W. G. Scarlett, USA: Sage Publication (Chapter 1).

Eagle, R. S. (2002). "Accessing and assessing intelligence in individuals with lower functioning autism." Journal of Developmental Disabilities 9: 45-53.

Fithri, H. (2011). "Religious Therapy as One of An Alternative Ways In Getting Educational Betterment for Children with Autism Spectrum Disorder." ProcediaSocial and Behavioral Sciences 29: 1782-1787.

Frost, J. L. (1992). Play and playscapes, Delmar Albany, NY.

Grandin, T. (1995). "How people with autism think." Learning and cognition in autism: $137-156$.

Grandin, T. (1995). Thinking in pictures: And other reports from my life with autism, Doubleday (New York).

Grandin, T. (1997). "A personal perspective on autism." Handbook of Autism and Pervasive Developmental Disorders (Cohen, DJ and Volkmar, FR, eds): 10321042.

Gus, L. (2000). "Autism: Promoting peer understanding." Educational Psychology in Practice 16(4): 461-468.

Ingersoll, B. (2008). "The effect of context on imitation skills in children with autism." Research in Autism Spectrum Disorders 2(2): 332-340.

Irna Wati Amusin, S. S. I., Mohd Yakub @ Zulkifli Bin Mohd Yusof (2012). KAEDAH AL-JABARI: SUATU PENGENALAN. In International Seminar On al-Qur'an In Contemporary Society (SQ 2012), Kuala Terengganu,Terengganu, Malaysia.

Jolliffe, T., R. Lansdown, et al. (2001). "Autism: a personal account." Learning, Space and Identity 2: 42.

Madihah Haji Mohamad (1992). Pembelajaran al Quran di kalangan pelajar-pelajar Sekolah Menengah: Satu tinjauan di daerah Kuala Terengganu, Terengganu Darul Iman.

Meltzoff, A. N. (2002). "Elements of a developmental theory of imitation." The imitative mind: Development, evolution, and brain bases: 19-41. 
Noh, M. A. C. (2004). "Celik Al-Quran Pelajar Tingkatan Satu Zon Pudu Kuala Lumpur. Projek Penyelidikan. Universiti Kebangsaan Malaysia."

Nusir, S., I. Alsmadi, et al. (2011). Designing an interactive multimedia learning system for the children of primary schools in Jordan. Global Engineering Education Conference (EDUCON), 2011 IEEE, IEEE.

O'Connor, K. (2011). "Auditory processing in autism spectrum disorder: A review." Neuroscience \& Biobehavioral Reviews.

Osterling, J. and G. Dawson (1994). "Early recognition of children with autism: A study of first birthday home videotapes." Journal of autism and developmental disorders 24(3): 247-257.

Prensky, M. (2001). "Digital natives, digital immigrants part 1." On the horizon 9(5): $1-6$.

Robins, D. L., D. Fein, et al. (2001). "The Modified Checklist for Autism in Toddlers: An initial study investigating the early detection of autism and pervasive developmental disorders." Journal of autism and developmental disorders 31(2): 131-144.

Rogers, S. and L. Bennetto (2000). "Intersubjectivity in autism: The roles of imitation and executive function." Autism spectrum disorders: A transactional developmental perspective: 79-107.

Rogers, S. J. (1999). "An examination of the imitation deficit in autism."

Rojahn, J., M. Lederer, et al. (1995). "Facial emotion recognition by persons with mental retardation: A review of the experimental literature." Research in Developmental Disabilities.

Ross, D. E. and R. D. Greer (2003). "Generalized imitation and the mand: Inducing first instances of speech in young children with autism." Research in Developmental Disabilities 24(1): 58-74.

Scarlett, E. M. D. a. W. G. (2006). The Encyclopedia of Religious and Spiritual Development

Smith, I. M. and S. E. Bryson (1994). "Imitation and action in autism: a critical review." Psychological Bulletin; Psychological Bulletin 116(2): 259.

Stone, W. L. and P. J. Yoder (2001). "Predicting spoken language level in children with autism spectrum disorders." Autism 5(4): 341-361.

Van Rijn, H. and P. J. Stappers (2008). "The puzzling life of autistic toddlers: design guidelines from the LINKX project." Advances in Human-Computer Interaction.

Volkmar, F. R. (2007). Autism and pervasive development disorder, Cambridge University Press.

Yusoff, N. M. R. N. (2005). Penilaian kemahiran mendengar dalam kurikulum Bahasa Arab Komunikasi di sekolah-sekolah agama Kerajaan Negeri

Zulkurnaini, N. A., R. S. S. A. Kadir, et al. (2012). The Comparison between Listening to Al-Quran and Listening to Classical Music on the Brainwave Signal for the Alpha Band. Intelligent Systems, Modelling and Simulation (ISMS), 2012 Third International Conference on, IEEE. 